\title{
Positioning Your Ranch for Business Succession
}

\section{By Dick Wittman and J. D. Radakovich}

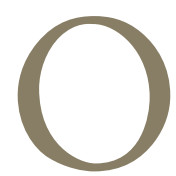

$\mathrm{n}$ his death bed, Captain Richard King, founder of the King Ranch, is quoted as saying, “... tell him not to let a foot of dear old Santa Gertrudis get away from us..." Seven generations later, his heirs have met that challenge, and the ranch Captain Richard King founded continues to thrive. For generations ranch owners of all types and sizes and from all regions of the country have sought to follow this example by leaving their children and grandchildren with the ranch they created. To start and build a ranch is noteworthy, but to enhance future generations with a sustaining legacy is exceptional. As few as $30 \%$ of family businesses make it to the second generation, and less than $10 \%$ are successfully passed to the third generation. Facing such tough odds, it is understandable that ranch families might assume that passing the ranch on could never work out for them. When ranch families allow succession to happen to them, this prophecy is often realized. However, some ranchers have made the proactive choice to shape the course of succession, rather than be shaped by it. These ranching families enjoy the fruits of nurturing and maintaining a ranching legacy.

But thinking and talking in generalities about succession plans is not enough. A transition decision is not made until it is put down on paper. The issues of succession need clear written documentation outlining what has been agreed upon concerning the transfer of management and ownership to the affected stakeholders. This quasi-contract will be relied on by parties exiting and entering the business, and it needs to document the important particulars of family conversations and verbal agreements so that they will not be lost to fading human memories.

Two common mistakes in succession planning are the assumptions that everyone in the ranch family deserves to work for equal pay and needs to take ownership in equal proportions. This egalitarian mindset can cause transition problems for two reasons: 1) more often than not, equal does not represent fair compensation for the amount of effort expended by each family member, and 2) the relationship between management and ownership is blurred. Ownership and management are fundamental concepts in any business and need to be addressed separately in succession planning, particularly when dealing with families. Each member of the family needs to make a decision as to which role they will play in the ranch business. Some family members may want a position in the management of the ranch. Others may want to participate by providing labor. Others may desire to have an ownership role. A few will find it appropriate to have positions as an owner and in management and labor. This choice is critical because it differentiates the roles assumed as the ranch business moves into the future. Making this choice puts the responsibility for it squarely in each family member's lap, where it belongs.

\section{Defining the Plan}

The usual focus for succession planning by owners and their advisors (attorneys, insurance agents, and accountants) is to answer questions about legal documents and proper business entities. During these planning meetings, questions will be answered about the structure of buyout agreements, wills, and about the insurance and risk management tools necessary to insure liquidity and to facilitate transfers. During this process, particular emphasis is placed on reducing inheritance tax. Focusing on how ranch wealth is transferred is essential and requires thoughtful deliberation, but it should not drive the transition. A successful transition needs to maintain a viable ranching operation, with emphasis on continuity in management, while transferring ranch ownership.

A critical first step in successful succession planning is documenting business goals and ranch assets into a form that gives advisors (attorneys, insurance agents, and accountants) insight into the ranch family and its ranching business. This process documents several important aspects: 1) the mission, vision, values, and goals of the ranch family and individual family members; 2) financial information and trends; 3) insurance information; and 4) biographical sketches of active members of the ranch including stakeholders with potential to join the ranch either as labor, management, or owners. Questions about the financial viability of the ranch business should be addressed and answered in the beginning stages of succession planning. For example, are there management or staff positions that need to be filled now or in the future? Will the ranch need 
additional financial capital? Does the ranch have the capacity to support current and future families desiring to ranch? The process of answering these questions can be as valuable as the answers themselves.

\section{Mission, Vision, Values, and Goals}

The ability of a ranching family to come together and communicate a shared sense of purpose is something that will yield dividends throughout the succession planning process. Defining the mission, vision, goals, and values of the ranching family will help the process. The mission statement defines the essence of the ranch-the reason for its existence. Vision is an idealized description of a desired outcome or an image of the ranch in the future. Values determine what behaviors or methods are acceptable for achieving the vision. ${ }^{2}$ Agreement on these principles is essential for conveying ranch ownership from one generation to the next.

It is best if the successor of the ranch is integrated into a functioning ranch with an established mission, vision, and values that are written down. Conflicts in operating philosophies and core values are generally recognizable when they occur, but they are often overlooked when the desire to keep the ranch in the family is strong. In some instances, the current owner may rationalize that a possible successor will mature and that his or her attitudes will change when given responsibility. However, experience demonstrates that personalities rarely change nor do attitudes or values. Confronting these realities early helps to avoid serious problems later.

Setting goals is fundamental to achieving a ranch vision. Surveys of agribusinesses indicate that only $30 \%$ of farmers and ranchers have written goals and objectives. One reason for lack of goal setting is that many people in ranch families have a fear of the ideas or expectations of others. In fact, most feel a sense of relief during planning sessions when everyone commits their goals to paper and many similarities are found among stakeholders. Goals do not have to be fancy or highly structured, but they must come from the heart, and they must be written on paper. Once all the stakeholders' wishes and intentions are identified, myths and erroneous assumptions can be dispelled.

\section{Organization and Description of Roles}

The family ranch may have existed for generations without clearly written job descriptions that include specific areas of responsibility and lines of accountability. Organizational structure and responsibilities are clearly defined in the minds of one or two people on the ranch; usually the ranch patriarch and matriarch. As ranching businesses increase in complexity and involve more people working together, it is increasingly important to explicitly address organizational issues during the transition-planning process. Desirable successors returning to the ranch are often well educated and can be better compensated elsewhere. Most will want some ownership in the ranch along with management responsibilities. Qualified successors will also want to know clearly what their role will be and what authority they have. They will also expect clearly defined performance expectations and criteria for compensation. Owners should be compelled to provide clarity to qualified successors, because alternative successors are likely to be less capable and less committed.

Written job descriptions are critical management tools that apply to both family members and non-family employees. They can seem overly bureaucratic, and many ranch families resist their use. In his book, Good to Great, Jim Collins emphasizes the importance of getting the right people on the bus, getting those on the bus in the right seats, and getting the wrong people off the bus. ${ }^{3}$ Written job descriptions defining the ranch's human resources benefit succession planning in the following ways: 1) they define unnecessary redundancy in work assignments that is needed before considering hiring or bringing a family member into the business; 2) they describe needed skills and qualifications when hiring to fill vacant positions; 3) they define a successor's duties and eliminate the perception that family members are "owed" a job; 4) they provide a basis for accountability and skill development; and 5) they provide an objective basis for performance appraisals.

Standardized operating procedures and policies aid succession in similar ways. Like job descriptions and vision statements, standard operating procedures are good business-management tools that help avoid conflicts. Workshop surveys indicate that $36 \%$ of progressive agricultural businesses have written policies in place. Not having standard policies can create communication nightmares for ranch owners and managers. Table 1 lists some potential policy land mines. Owners need to know if their policies

\section{Table 1. Suggested ranch policy discussion} points

1. Housing

- Who gets ranch housing?

- Who maintains housing?

- How is housing factored into compensation?

2. Company and personal vehicles

- Who pays for maintenance, insurance, fuel, etc.?

3. Expense accounts and reimbursements

4. Compensation for managers and laborers

5. Terms of equity withdraw from the ranch

6. Pricing transactions that involve insiders and inter-entity relationships

7. Medical benefits, disability, and life insurance

8. Retirement and pension plans

9. Benefit continuation in the event of death or disability

10. Expectation of work days, vacation time, and sick leave

11. Business buyout plan for someone who wants out

12. Restrictions on off-ranch activities or conflicts of interest 


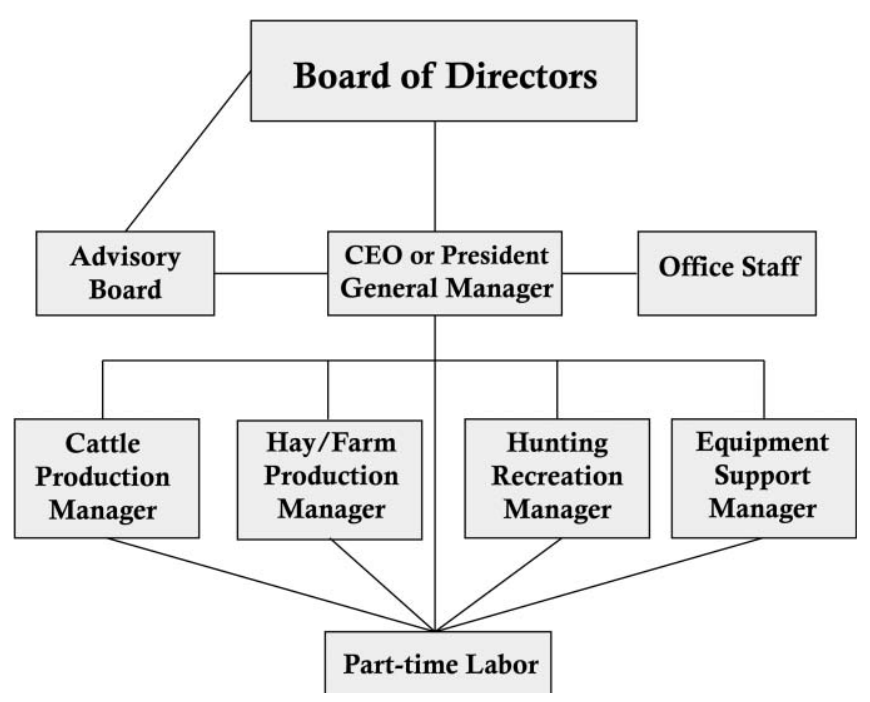

Figure 1. Example organizational structure for a family ranch business.

and standardized operating procedures either attract or drive away potential successors. Early homework in succession planning should involve all the stakeholders on the ranch; each should write down the current practices in each of the policy areas listed in Table 1. Ranch personnel, including spouses, are often confused by inconsistent expectations and procedures that often become the root cause of both stated and unstated conflicts.

An organizational chart is another management tool that aides in succession planning. At a minimum the chart should show key members of the management team, primary areas of responsibility, and lines of authority and accountability flowing from the board of directors through management to full-time and seasonal labor. Figure 1 shows an example of an organizational chart for a family ranch. Perceptions influence how people describe their organizations. When comparing organizational charts among family members within a ranch, it can be hard to tell if they are describing the same ranch. Discussing differing perceptions of organizational relationships among stakeholders can lead to rational business discussions about emotionally sensitive issues. Some of the issues that will need to be addressed are listed in Table 2. Rarely do stakeholders acknowledge the existence of a board of directors or advisory board, and often there is no indication that the family ranch has a chief executive officer (CEO). In reality, CEOs exist in almost all family businesses.

A critical succession-planning issue is defining the role of the retiring ranch $\mathrm{CEO}$ when a new $\mathrm{CEO}$ assumes management responsibilities. The options are many. One possibility is a seat on the ranch's board of directors, possibly even as the board's chair. The chair's job can be a full-time position concentrating on refining business policies, investment analysis, strategic planning, performance review, and/or mentoring. An exiting CEO reluctant to abandon his or her position can cause hardships; few organizations can survive with more than one CEO.
Table 2. Suggested discussion questions for family ranches concerning organizational issues

1. Who is the chief executive officer (CEO)?

2. Who reports to the CEO, and how is accountability enforced?

3. Is there upward mobility with an obvious career path?

4. What attributes should the ranch look for in a successor CEO?

5. What does the current CEO do after a new CEO has been groomed for succession?

6. What is the role of the board of directors?

7. Can formal recognition of the board of directors enhance succession?

8. Is there opportunity for the retiring CEO to maintain a less active leadership role as board chairman?

\section{Communication and Conflict Management}

To sustain a ranching legacy, ranching families need to communicate effectively. A commitment to effective communication should be addressed in the core value statements that emphasize respect and professionalism. Regular meetings help succession planning. Each meeting should have a specific agenda to facilitate preparedness and ensure goals are met. With succession planning meetings, emotional topics are encountered. As a result, ground rules for meetings need to be clearly established and agreed on by all participants. A few rules that ranch families may want to use are listed in Table 3.

Openness and candor among family members is essential when dealing with financial issues related to the ranch business. A critical step in preparing for business transition and estate planning is to organize financial information so

\section{Table 3. Suggested ground rules for family ranch} meetings

1. Participants must aim to be problem solvers. They must brainstorm solutions and work together, not against one another.

2. Participants must focus on the opportunity or problem, not the people. They must accept the validity of the other's position.

3. Participants must work toward a win-win solution. A win-lose solution is unacceptable.

4. The group must satisfy the underlying interests. Personal compromise for the sake of the business may be required.

5. Business roles on the ranch take precedence over family status and pecking orders.

6. Unprofessional communication should not be tolerated.

7. Participants must understand how different personality types impact how communication is offered and received. 
that it can be shared with family members and business advisors. Details of financial issues are included in the following documents: budgets, strategic plans, long-term debt, service obligations, financial trends (at least five years) showing cash and accrual net income, cost and market-value balance sheets (with deferred tax), and key financial ratios. All need to be organized to provide a clear picture of the business. Summaries of active insurance policies with beneficiary listings, premiums, and gifts made or already committed by family members need to be identified at the start of the planning process. Solid financial planning is a keystone of any successful ranching business and provides immense benefits to the succession-planning process.

The desire to attract successors must be accompanied by a willingness to share intricate financial details about the ranch. This is disquieting for some owners. From the successors' perspective it is unreasonable for them to give up careers elsewhere to fully invest themselves in a ranching business without knowing its operating performance or financial position. On the other hand, owners may worry that once the successor realizes the ranch's value, they will become greedy. The opposite may also be true if the ranch is in poor shape financially. The concern then is that openness may drive successors away. Often, the ranch owners may understand the importance of sharing this information, but the habit of privacy is so ingrained they are unable to fully disclose the situation. Advisory boards can provide assistance working through some of these communication issues.

\section{Pitfalls}

When it comes to succession planning, procrastination is the biggest pitfall. Most business owners admit they put off succession planning much longer than they should. Complicated procedures, costly legal fees, and dealing with family relationships are reasons given for procrastinating. In many cases attending to other business goals leaves little time for planning the eventual transition of ownership. However, early dialogue about succession planning makes the process easier by acknowledging the subject and providing time for people to become comfortable with the topic.

The scope of transitioning ranch ownership and management may seem daunting when viewed as a whole. However, procrastination can be avoided and the process made easier by breaking the planning process into manageable pieces. Action items can be created within a time table that includes each piece of the plan and lists who is accountable for each segment. Waiting until the last minute to start this process impairs the ranch's ability to transition effectively and could have devastating effects in a challenging business environment.

Expectations from the owners and successors can be challenging. Assumptions about ownership and succession of property are difficult and cause the demise of many ranching families. Starting the process of communicating and planning early allows for these assumptions and expectations to be addressed before they become ingrained in the minds of stakeholders.

Deciding who will become the CEO can be difficult, especially if the selection is made among siblings when mom or dad is no longer present. Cultural practices have traditionally defined who takes over management. The oldest son is often anointed successor regardless of qualifications or previous experience. In a modern world, this practice does not measure up. Selection needs to be openly objective, with honest dialogue between all members in family's ranching business.

\section{Summary and Concluding Thoughts}

All ranches and all ranch families are different, an attribute of limitless landscapes and a rancher's sense of independence and uniqueness. Because of this, no two transition plans are the same. There is no single recipe for succession. A strong commitment to communication and to working toward a unified vision of the ranch is required. Decisions need to be made about which roles family members will assume: owner, management, and labor. Owners must be realistic about the capacity of the ranch by knowing how many people it can support. All parties must commit to regular and honest performance evaluations as they move down the trail toward succession.

Successful transitions seldom occur without the aid of competent business advisors. Accountants, attorneys, insurance agents, and investment advisors must be engaged, and they must work seamlessly together, not as a group of individuals working independently.

Putting the plan into writing means the ranching family has made the key decisions and is willing to stand behind them, working with heirs, successors, and advisors throughout the implementation process. Owners and heirs can mature with peace of mind knowing a comprehensive estate plan is in place to protect their ranching legacy.

\section{References}

1. Dunn, B. H., J. Davis, M. Beutler, A. Arzeno, R. N. Gates. 2008. Sustaining the legacy: management and wealth transfer planning for ranches. Kingsville, TX, USA: King Ranch Institute for Ranch Management, Texas A\&M University Kingsville. $46 \mathrm{p}$.

2. Kilgore, C. 2008. Our job as leaders: building shared vision and creating conditions for personal mastery. Kingsville, TX, USA: Presentation at King Ranch Institute for Ranch Management, November 2008. 22 p.

3. Collins, J. 2001. Good to great. New York, NY, USA: HarperCollins Publishers Inc. 300 p.

Authors are Agricultural Family Business Consultant, Managing Partner, Wittman Farms, Culdesac, ID 83524, USA, dwittman@lewiston.com (Wittman); and Graduate Fellow, King Ranch Institute for Ranch Management, Texas AङM University-Kingsville, Kingsville, TX 78363, USA, jason. radakovich@students.tamuk.edu (Radakovich). 